\title{
過去24年間の頭頸部領域脂肪腫30症例の臨床統計的観察
}

\author{
过野元博・由井俊平・墨哲郎・森 悦 秀 \\ 中澤光博・松 本 憲・菅原利夫・作田正義
}

\section{Clinical and statistical observation on lipoma of the oral cavity and neck in our department during past 24 years}

\author{
Motohiro Tsujino - Shunpei YuI - Tetsurou SumI - Yoshihide Mori \\ Mitsuhiro Nakazawa - Ken Matsumoto - Toshio Sugahara - Masayoshi Sakuda
}

\begin{abstract}
Lipoma is a benign tumor derived from nonepithelial origin and may occur almost anywhere on the body. In the oral cavity, however, lipoma is a relatively rare tumor.

In this report, 30 cases of lipomas treated in our department during past 24 years are reviewed.

1) The incidence of lipoma in our department is $4.1 \%$ of all benign tumor. Salivary gland tumors and epulis are excluded in this report.

2) 16 patients were male and 14 female.

3 ) Age ranged from 47-day-old baby to an 82-year-old man; mean age was 47.9 years.

4) 11 cases were in the buccal mucosa, 4 in the mucogingival junction, 3 in the retromolar pad, 3 in the tongue, etc.

5 ) Tumor size ranged fron $5 \times 5 \mathrm{~mm}$ to $50 \times 50 \times 40 \mathrm{~mm}$ in the oral cavity, and from 25 $\times 25 \mathrm{~mm}$ to $80 \times 50 \mathrm{~mm}$ out of the oral cavity.

6) 24 tumors were histologically diagnosed as lipoma; 5 as fibrolipoma, and 1 as angiomyolipoma.
\end{abstract}

Key words: lipoma (脂肪腫), head and neck region (頭頸部頋域), statistical study (統計的 観察)

\section{緒言}

脂肪腫は腫場実質細胞が脂肪組織よりなる良性腫汪 で, 主として皮下組織に発生し口腔領域では他の非歯原 性腫湯に比べてその発生頻度は低く，比較的まれである とされている1 3). 今回，われわれは過去 24 年間に経験 した脂肪腫30例について集計を行い，臨床的および文献

大阪大学齿学部口腔外科学第 2 講座

（主任：作田正義教授）

The Second Department of Oral and Maxillofacial Surgery, Osaka University Faculty of Dentistry

(Chief: Prof. Masayoshi SAKUDA)

受付日：昭和63年12月 26 日
的に検討を加え報告する.

\section{対 象 症 例}

対象症例は昭和39年 (1964年) から昭和62年 (1987年) までの 24 年間に当科を受診し腫瘍摘出を受け病理組織学 的検索により，脂肪腫と診断された 30 例である．診断名 は，H-E 染色および一部特殊染色を施した 組織標本を 検討して確定したものである.

$$
\text { 結果 }
$$

過去24年間に脂肪腫と診断されたものは，表 1 に示す ように30例であった。この間に当科における唾萑腺腫瘍 およびェプーリスを除き，病理組織学的に良性腫場と診 
表 1 当科で過去24年間に経過した脂肪腫30例

\begin{tabular}{|c|c|c|c|c|c|c|}
\hline 症例 & 年齿 & 性別 & 部 位 & 大きさ & 病理組織訩断 & 病恼期間 \\
\hline 1 & 51 & 우 & 頓 粘 膜 & 小豆大 & 脂 肪 腫 & 2 週 \\
\hline 2 & 55 & 우 & 頓 粘 膜 & 小指頭大 & 脂 肪 腫 & 1 年 \\
\hline 3 & 4 & 占 & 煩 粘 膜 & $50 \times 50 \times 40 \mathrm{~mm}$ & 脂 助 腫 & 3. 5 年 \\
\hline 4 & 1.2 & 우 & 舌 & 小豆大 & 線維脂肪腫 & 2 只月 \\
\hline 5 & 55 & $\hat{0}$ & 曾肉頓移行部 & $10 \times 10 \mathrm{~mm}$ & 脂 肪 腫 & 7 か月 \\
\hline 6 & 59 & $\hat{\delta}$ & 煩 粘 膜 & 沜 卵 大 & 線維脂肪腫 & 不明 \\
\hline 7 & 0.1 & ऽ & 上顎柊肉 & $9 \times 5 \times 3 \mathrm{~mm}$ & 脂 肪 腫 & 1.5か月 \\
\hline 8 & 67 & 우 & 下靧後臼䔥部 & 小豆大 & 脂 肪 腫 & 1 年 \\
\hline 9 & 33 & 우 & 舌 & $10 \times 8 \mathrm{~mm}$ & 脂 肪 腫 & 5 年 \\
\hline 10 & 26 & $\hat{\sigma}$ & 幽肉頓移行部 & $10 \times 10 \mathrm{~mm}$ & 脂 肪 腫 & 2 か月 \\
\hline 11 & 82 & 今 & 煩 粘 膜 & $42 \times 30 \times 22 \mathrm{~mm}$ & 脂 肪 腫 & 15年 \\
\hline 12 & 52 & 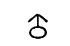 & 煩 粘 膜 & $15 \times 15 \mathrm{~mm}$ & 脂 肪 腫 & 7 年 \\
\hline 13 & 2 & $\hat{\delta}$ & 煩 粘 膜 & $32 \times 32 \times 8 \mathrm{~mm}$ & 線維脂肪腫 & 1 週 \\
\hline 14 & 52 & $\uparrow$ & 读肉頓移行部 & $20 \times 20 \mathrm{~mm}$ & 脂 肪 腫 & 5 年 \\
\hline 15 & 56 & 우 & 下顎後臼檤部 & $8 \times 8 \mathrm{~mm}$ & 脂肪腫 & 不明 \\
\hline 16 & 65 & 우 & 頓 粘 膜 & $30 \times 30 \mathrm{~mm}$ & 脂 肪 腫 & 40年 \\
\hline 17 & 33 & 우 & 頓 粘 膜 & $45 \times 40 \mathrm{~mm}$ & 脂 肪 腫 & 4 か月 \\
\hline 18 & 37 & $\hat{\jmath}$ & 軟口蓋 & $15 \times 15 \mathrm{~mm}$ & 脂 肪腫 & 3 年 \\
\hline 19 & 57 & 우 & 口底 & $45 \times 30 \mathrm{~mm}$ & 脂肪腫 & 7 年 \\
\hline 20 & 72 & 우 & 下買後臼楿部 & $10 \times 10 \mathrm{~mm}$ & 線維脂肪腫 & 2 年 \\
\hline 21 & 42 & 今 & 顎 下 部 & $80 \times 50 \mathrm{~mm}$ & 脂肪腫 & 2.5 年 \\
\hline 22 & 72 & $\hat{\jmath}$ & 齿肉煩移行部 & $30 \times 30 \mathrm{~mm}$ & 脂 助 腫 & 1 か月 \\
\hline 23 & 57 & 우 & オトガイ下部 & 小指頭大 & 脂 肪 腫 & 8 年 \\
\hline 24 & 44 & $\hat{\delta}$ & 硬口蓋 & $5 \times 5 \mathrm{~mm}$ & 血管笳脂肪腫 & 2 か月 \\
\hline 25 & 66 & 우 & 舌 & $7 \times 7 \mathrm{~mm}$ & 脂 肪 腫 & 25年 \\
\hline 26 & 57 & $\hat{\sigma}$ & 頓 粘 膜 & $8 \times 8 \mathrm{~mm}$ & 脂肪腫 & 1 か月 \\
\hline 27 & 54 & 우 & 上 頸 部 & $25 \times 25 \mathrm{~mm}$ & 脂 肪 腫 & 8 か月 \\
\hline 28 & 62 & 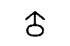 & 頓 粘 膜 & $25 \times 25 \mathrm{~mm}$ & 脂 肪 腫 & 3.5 年 \\
\hline 29 & 61 & 우 & 下唇 & $10 \times 10 \mathrm{~mm}$ & 線維脂肪原 & 3 年 \\
\hline 30 & 63 & $\hat{\diamond}$ & 唇 & $8 \times 8 \mathrm{~mm}$ & 脂 助 腫 & 1 か月 \\
\hline
\end{tabular}

断されたものは 735 例で，そのうち脂肪腫の占める割合 は $4.1 \%$ であった。

発生年㱓では，生後47日の乳児から82歳にわたり，年 代別では 50 歳代が 11 例 $36.7 \%$ と最も多く，平均年齢は 47. 9歳であった。

性別では，男性16例，女性14例であった（図1）.

発生部位では，煩粘膜が11例 $36.7 \%$ を占め最も多く， ついで歯肉煩移行部 4 例, 後曰歯部 3 例, 舌 3 例, 下唇 2 例, 以下口底, 軟口蓋, 硬口蓋, 歯肉が 1 例すう認め られた。腔外では，顎下部，オトガイ下部，頸部にそ れぞれ 1 例認められた（表 2).

病悩期間については，1 週間から最長40年までてわた っていた。

大きさについては，口腔内にできたものでは直径 5 $\mathrm{mm}$ 程度のものから最大 $50 \times 50 \times 40 \mathrm{~mm}$ の煩粘膜にで きたものまで種々の大きさを示していた．口腔外のもの は, 直径 $25 \mathrm{~mm}$ のものから最大 $80 \times 50 \mathrm{~mm}$ のものが みられた。

病理組織型別では，表了のように脂肪腫24例，線維脂 肪腫 5 例, 血管筋脂肪腫 1 例であった。

$$
\text { 考察 }
$$

脂肪腫は腫瘍の実質細胞が成熟した脂肪組織からなる 非上皮性の良性腫漡で，好発部位は皮下，特に頸部，肩 甲部, 背部, 詯部, 四肢伸側である.

全身に発生する良性腫湯のらち脂肪腫の発現頻度は MacGregor ら 4 によると 4 〜 $5 \%$ ，遠城寺ら 


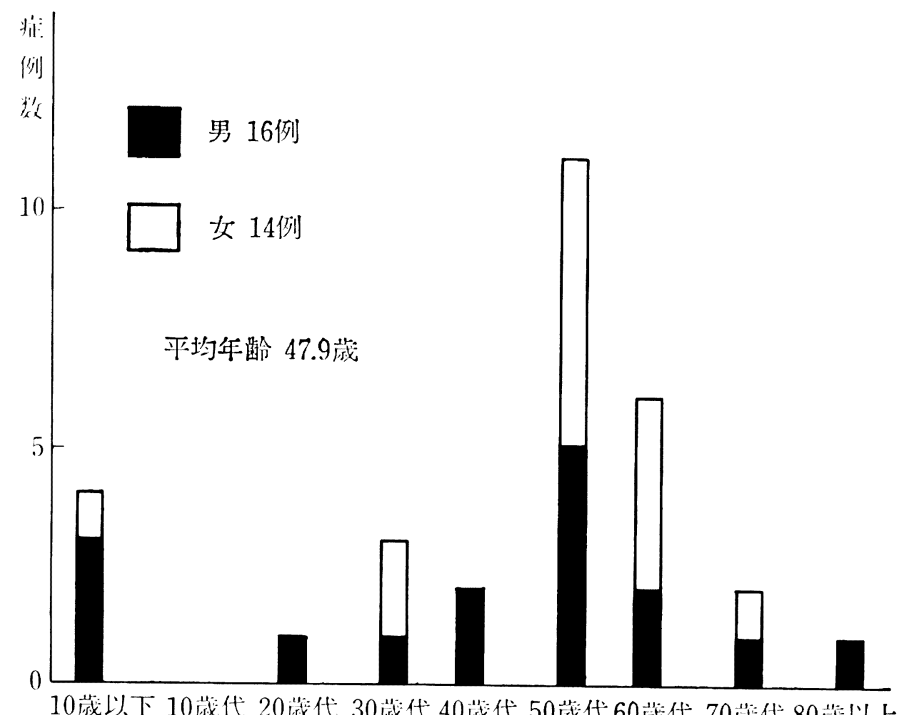

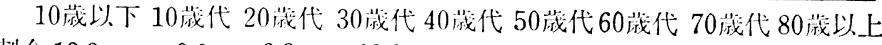
$\begin{array}{lllllllll}\text { 制合 } 13.3 & 0.0 & 3.3 & 10.0 & 6.7 & 36.7 & 20.0 & 6.7 & 3.3\end{array}$

図 1 脂肪腫 30 例の年齢, 性別の分布

表 2 脂肪腫30例の部位, 性別の分布

\begin{tabular}{|c|c|c|c|c|}
\hline 部 位 & 男 & 女 & 計 & 割合 \\
\hline 頓粘膜 & 7 & 4 & 11 & $36.7 \%$ \\
\hline 歯肉煩移行部 & 4 & 0 & 4 & $13.3 \%$ \\
\hline 後曰歯部 & 0 & 3 & 3 & $10.0 \%$ \\
\hline 舌 & 0 & 3 & 3 & $10.0 \%$ \\
\hline 下唇 & 1 & 1 & 2 & $6.7 \%$ \\
\hline 口底 & 0 & 1 & 1 & $3.3 \%$ \\
\hline 軟口蓋 & 1 & 0 & 1 & $3.3 \%$ \\
\hline 硬口蓋 & 1 & 0 & 1 & $3.3 \%$ \\
\hline 歯肉 & 1 & 0 & 1 & $3.3 \%$ \\
\hline 顎下部 & 1 & 0 & 1 & $3.3 \%$ \\
\hline オトガイ下部 & 0 & 1 & 1 & $3.3 \%$ \\
\hline 頸部 & 0 & 1 & 1 & $3.3 \%$ \\
\hline
\end{tabular}

と 8,086 例中 $19.8 \%$, Fukuoka ら ${ }^{6)}$ によると $17.5 \%$ 報 告されている.

一方, 口腔領域に発現する良性腫瘍のうち脂肪腫の頻 度は表 4 のように多くの 報告があるがそのほとんどは $2 \sim 5 \%$ 前後 $8 \sim 12,14 \sim 17,20,21)$ となっている. 乙かし，な かには $7 \%$ 台の高い割合の報告 ${ }^{18,19)}$ もみらる。これ は，森ら ${ }^{22)}$ も述べているように，良性腫瘍のなかに喠液 腺腫瘍を含んでいるもの，歯原性腫瘍を除外しているも のなど，さまざまであり母数にあたる良性腫湯の範囲の 設定の相違が脂肪腫の発生率のばらつきを大きくしてい ると考えるのが妥当であろう.
表 3 脂肪腫 30 例の病理組型別の分布

\begin{tabular}{l|r|r|r}
\hline \multicolumn{1}{c|}{ 組織型 } & 男 & 女 & 計 \\
\hline 脂肪腫 & 13 & 11 & 24 \\
線踓脂肪腫 & 2 & 3 & 5 \\
血管筋脂肪腫 & 1 & 0 & 1 \\
\hline
\end{tabular}

いずれにしても，石川ら ${ }^{23)}$ の記載にみられるように口 腔領域に拈ける脂肪腫の発現はさほどまれとはいえない ようである。

自験例では，唾液腺腫瘍およびェプーリスを除き，粦 原性腫瘍を含めて母集団を設定した場合 735 例中30例で 4.1\%であった．また，真の腫瘍とはいえない irritation fibroma を除いて母集団を設定すると 492 例中の $6.1 \%$ となった（表 4).

発生年䶚については，諸家の報告は40歳以上で多発と

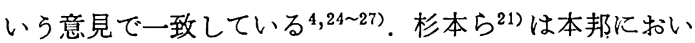
て買口腔領域から報告された脂肪腫 220 例を集計し， 60 歳代に $23.2 \%$ と最も多発し，以下50歳代 $20.9 \% ， 30$ 歳代 40歳代がそれぞれ13.6\%で，平均年齡は48.6歳であった としている.

自験例では，図1のように50歳代が11例，36.7\%と最 8 多く, 以下 60 歳代 6 例，20\%，10 歳以下 4 例，13.3 $\%$ ，平均年齡47.9歳となり諸家の報告とほぼ一致した結 果が得られたが，10歳以下に若干多くの症例が認められ た。

性別では，脂肪腫全体としては男性に多いとするも 
表 4 文献中にみられた口腔内良性腫汮中に 占める脂肪腫の割合

\begin{tabular}{|c|c|c|c|}
\hline 報告者（報告年） & 脂肪腫数 & 良性腫湯総数| & 割合 $(\%)$ \\
\hline 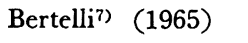 & 6 & 633 & 0.95 \\
\hline Wehrle $^{8)}$ (1965) & 4 & 180 & 2.2 \\
\hline Visscher $^{9)} \quad$ (1982) & 19 & 792 & 2.4 \\
\hline 久野ら ${ }^{10)}(1978)$ & 5 & 204 & 2.5 \\
\hline 岡野 ${ }^{11)}$ (1979) & 10 & 666 & 1.5 \\
\hline 田中ら ${ }^{12)}$ (1980) & 8 & 338 & 2.4 \\
\hline 八重垣ら ${ }^{13)}$ (1980) & 4 & 764 & 0.5 \\
\hline 鶴野 (14) $^{1981)}$ & 9 & 728 & 1.2 \\
\hline 千葉ら ${ }^{15)}$ (1982) & 13 & 585 & 2.2 \\
\hline 伊地知 ${ }^{16)}$ (1982) & 2 & 45 & 4.4 \\
\hline 伊藤ら ${ }^{17)}$ (1982) & 3 & 72 & 4.2 \\
\hline 三上ら ${ }^{18)}$ (1984) & 4 & 52 & 7.7 \\
\hline 吉嶺 $5^{19)}$ (1985) & 3 & 57 & 7.7 \\
\hline 柴田 ${ }^{20)}$ (1986) & 2 & 115 & 1.7 \\
\hline 杉本ら ${ }^{21)}$ (1988) & 3 & 120 & 2.5 \\
\hline \multirow[t]{2}{*}{ 自験例 } & 30 & 735 & 4.1 \\
\hline & & $(492)$ & $6.1)$ \\
\hline
\end{tabular}

（）は irritation fibroma を除いた場合

$の^{9,12,24,25,27)}$ が多いが，一方では女性に多いとするも

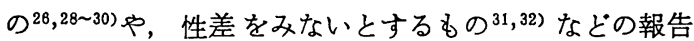
がみられ特定の傾向はみられないようである，むしろ， 脂肪腫全体としてみた場合，性別による著差はないと考 えるべきであろう，自験例では，男性16例，女性14例で あった。

発生部位については，表 5 のように打打むね煩粘膜が 最も多く30５0\%，ついで舌，口底がそれぞれ10２0 $\%$, 以下顎下部, 歯肉頓移行部, 口唇, 歯肉, 口蓋, な どに多いといら傾向で一致するようである．自験例で は，表 2 に示すように煩粘膜に最も多かったが，他の部 位は以上の報告とは必ずしも一致しなかった。

一方，発生部位と性別との関係を久た報告は多くはな いが, Visscher ${ }^{9}$ ，Rapidis ${ }^{25)}$ や森ら ${ }^{22)}$ によると口底扰よ び後臼歯部の脂肪腫は女性に多く，その他の部位では男 女同数であるという．自験例では，表 2 のように煩粘膜 および歯肉頓移行部に発生したものは男性に多く，後且 歯部および舌では女性に多い傾向がみられた。しかし， その意義については不明で今後の検討が必要と考えられ る.

大きさについては，種々の大きさのものが報告され ているが，杉本ら ${ }^{21)}$ の集計によると $2.0 \sim 3.0 \mathrm{~cm}$ の範 囲のものが最も多く $27.1 \%$ を占めていたとしている. 本邦に批ける 口腔外科領域での最大の脂肪腫はわれわ れの涉椫 し得た範囲 では奥村ら ${ }^{34)}$ の顎下部に発生した
表 5 文献中にみられた脂肪腫の部位別発生頻度

\begin{tabular}{|c|c|c|c|c|}
\hline 報告者 （年度） & 頓部 & 舌 & 口底 & 口居 \\
\hline MacGregor $^{4)}$ (1966) & $42.1 \%$ & $19.3 \%$ & $14.0 \%$ & $10.5 \%$ \\
\hline Hatziotis $^{24)}$ (1971) & $32.2 \%$ & $19.6 \%$ & $14.7 \%$ & $6.3 \%$ \\
\hline 刀根 ${ }^{26)}$ (1985) & $37.0 \%$ & $17.0 \%$ & $10.0 \%$ & $3.8 \%$ \\
\hline 村上5 ${ }^{33)}$ (1985) & $42.9 \%$ & $14.3 \%$ & $7.1 \%$ & $7.1 \%$ \\
\hline 鈴木ら ${ }^{27)}$ (1987) & $33.3 \%$ & $15.2 \%$ & $6.1 \%$ & $15.2 \%$ \\
\hline
\end{tabular}

$80 \times 130 \times 20 \mathrm{~mm}, 240 \mathrm{~g}$ のものが報告されている.

自験例においては，口腔内にできたものでは直径 5 $\mathrm{mm}$ 程度のものから最大 $50 \times 50 \times 40 \mathrm{~mm}$ の 4 歳男児の 頓粘膜にできたものまで種々の大きさを示していた，口 腔外のものでは直径 $25 \mathrm{~mm}$ のものから最大 $80 \times 50 \mathrm{~mm}$ のものがみられ，口腔内に発生したものよりやや大きい 傾向をらかがわせた。

病悩期間については，本腫瘍が良性でその発育が比較 的緩慢なため長い病悩期間を示す報告が多い，自験例で は，1年以内が 14 例と約半数を示したが， 5 年以上 10 年 未満が 4 例, 10 年以上が 3 例, 最長 40 年となっており, 本腫鈞のきわめて緩慢な增殖をらかがわせる.

脂肪腫の病理組織像については, 基質および腫瘍細胞 の性状により単純性脂肪腫, 線維脂肪腫, 血管脂肪腫, 血管笳脂肪腫, 化骨性脂肪腫, 粘液脂肪腫, 紡鍾細胞脂 肪腫, 多形性脂肪腫, 筋肉内脂肪腫なとに分類されてい る ${ }^{35)}$. 多くは単純珄脂肪腫あるいは線維脂肪腫のようて ある。自験例では，単純性脂肪腫24例，線維脂肪腫 5 例 に加えて血管筋脂肪腫 1 例がみられた。この血管笳脂肪 腫は，44歳男性の硬口蓋に発生したもので粘膜下に内皮 細胞で裹層された拡張した血管腔および平滑筇細胞を伴 っているのが認められた。

脂肪腫の発生機序については，一般的には組織異所発 生説，正常組織の過形成説などが報告されている．その 成因としては, 外傷, 僈性の刺激, 内分泌異常, 脂肪代 謝異常などがあげられているが，他の腫浧と同様，推察 の域を出ず，いまだ不明である.

治療法としては，外科的に腫陽を全摘出するのが一般 的である，全摘出した場合，再発は認められないのが通 常である。

結 語

昭和39年（1964年）から昭和62年（1987年）むでの24 年間に当科を受診した脂肪腫症例30例について臨床的拉 よび文献的に検討を加え報告した。

本論文の要旨の一部は，第15回日本口腔外科学会近畿 地方会（昭和62年12月，大阪市）飞扣いて発表した。 


\section{引用 文 献}

1) Gorlin, R.J. and Goldman, H.M.: Thoma's Oral Pathology II. 6 th Ed. Mosby Co, St Louis, 1970, p 880-881.

2) Geschickter, C.F.: Lipoid tumors. Amer J Cancer 21: 617-641 1934.

3) Simpson, H.E.: Lipoma of oral cavity. Oral Surg 12: 349-352 1959.

4) MacGregor, A.J. and Dyson, D.P.: Oral lipoma, A review of the literature and report of twelve new cases. Oral Surg 21: 770-777 1966.

5）遠城寺宗知, 岩崎 宏, 他: わが国に扰ける良 性㳄部組織腫懪 $-8,086$ 例の統計的微察一 癌 臨 20: 594-609 1974.

6) Fukuoka, Y., Kawahara, Y., et al.: Clinicopathological study of soft tissue tumors. J Lpn Orthop Assoc 53: 85-104 1979.

7) Bertelli, A.P.: Uncommon tumors of the tongue (lipoma and leiomyofibroma). Report of two cases. Oral Surg 19: 771-775 1965.

8) Wehrle, D.P., Emmings, F.G., et al.: Lipoma of the oral cavity. Report of four cases. Oral Surg 20: 138-140 1965.

9) Visscher, J.G.A.M.: Lipomas and fibrolipomas of the oral cavity. J Max-fac Surg 10: 1771811982.

10）久野吉雄, 佐藤田鶴子, 他：頓粘膜に発生した 脂肪腫の 1 症例飞ついて。蔽学 67: 388-392 1978.

11）岡野昌治, 成瀬 健, 他: 若年者の煩部に見ら れた粘液脂肪腫の 1 例。 日外誌 25：649-652 1979.

12）田中大順, 山本悦秀, 他 : 口腔領域に発生した 脂肪腫 8 例の臨床的観察。 日外誌 26：106810731980.

13）八重垣健, 亀山忠光, 他 : 舌に見られた脂肪腫 の 1 例。 日外誌 26: 1563-1567 1980 .

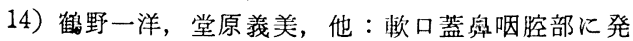
生した脂肪腫の 1 例。日口外誌 $27: 1052-1055$ 1981.

15）千葉博茂, 葛井正, 他：オトガイ下部に発生 した脂肪腫の 1 例。口科誌 31：102-107 1982.

16）伊知地明, 山岡 稳, 他 . 口腔内に発生した脂
肪腫の 2 症例. 松本檤学 8: 114-120 1982.

17）伊藤信明, 岡村悟, 他：乳児の頓部に発生し た脂肪腫の 1 例。 日外誌 28: 739-744 1982.

18）三上八郎, 木脇雅子, 他: 脂肪腫の 4 例。（抄） 口科誌 33: 6451984.

19）吉领真一郎, 大枝直樹, 他: 脂肪腫の 4 例。口 科誌 34: 202-206 1985 .

20）柴田隆夫, 水野明夫, 他: 口腔外科領域の㳄組 織良性腫㻛の臨床統計的㭘討。口科誌 35：1641701986.

21）杉本忠雄, 田辺昭博, 他：下屋に発生した脂肪 腫の 1 症例。 日外誌 34: 167-174 1988 .

22）森 悦秀, 加納康行, 他: 口腔底に発生した脂 肪腫の 1 症例と文献的考察. 日只外誌 31 : $585-$ 5901985.

23）石川梧朗, 秋吉正豊, 他: 口腔病理学 II, 改訂 版, 永末望店, 京都, 1982, 570-572.

24) Hatziotis, J. Ch.: Lipoma of the oral cavity. Oral Surg 31: 511-524 1971.

25) Rapidis, A.D.: Lipoma of the oral cavity. Int J Oral Surg 11: 30-35 1982.

26）刀根 功, 松田耕策, 他: 下唇に発生した脂肪 腫の 1 例。 日外訰 31：2816-2820 1985.

27）鈴木三郎, 塩入重彰, 他 : 頸部に発生した脂肪 腫の 1 症例と臨床統計的観察。 日只外誌 33: 1252-1257 1987.

28）倉地洋一, 紀村 享, 他: 下口唇に発生した脂 肪腫の 1 例. 日口外誌 26: 209-214 1980.

29) Bruce, K.W. and Royer, R.Q.: Lipoma of oral cavity. Report of three cases. Oral Surg 7: 930-938 1954.

30) Panders, A.K. and Scherpenisse, L.A.: Oral lipoma. Br J Oral Surg 5: 33-41 1967.

31）梶山稔, 古賀久保, 他: 脂肪腫の 2 例. 九州 蔯会誌 21：34-41 1967.

32）久野吉雄, 内山敏子, 他: 菌肉に発生した脂肪 腫の 1 例。 日外誌 19: 651-654 1973.

33）村上有二, 西方 聡, 他: 脂助腫 14 症例飞つい ての臨床的, 病理組織学的检討 (抄). 口科誌 34: 874-875 1985.

34）奥村康明，安岡 忠，他：菲胞性りンパ管腫を 疑った小児頭大の脂肪腫の 1 例. 日只外誌 33 : 1628-1633 1987.

35) Enzinger, F.M. and Weiss, S.W.: Soft tissue tumors. 2 nd Ed. Mosby Co, St Louis, 1988, p 301-345. 